\title{
CIF/IFC Student Awards
}

This is the second of three articles on CIF/IFC Awards and Prizes (1). This presentation deals with awards and prizes given by the Institute to students of Canadian forestry schools.

When the Canadian Society of Forest Engineers was founded early in 1908 it recognized Canadian forestry students by making provision for them to join the Society as "Student Members," although there was only one forestry school in Canada - that at Toronto, established in 1907. The schools at the universities of New Brunswick and Laval were established in 1908 and 1910, respectively, and that at the University of British Columbia more than a decade later. The first regular program of prizes to students was the Schlich Memorial Fund Award, started in 1935.

\section{Schlich Memorial Fund Award}

The Schlich Memorial Fund Award is named in honor of the late Sir William Schlich, who served as inspectorgeneral of forests for India, professor of forestry at Oxford University and was author of technical books in forestry used throughout the world. On his death in 1925 a memorial foundation was established in his name by the British Commonwealth Countries and the United States of America, the interest from which was to be given to a different country each year.

In 1934 Canada received about $\$ 300.00$, which was turned over to the C.S.F.E. The Society set up a fund, from which the interest totalled $\$ 15.00$ every two years and became known as the Schlich Memorial Prize. This prize, in the form of books on forestry, was usually awarded annually, sometimes every second year, in rotation to a student from each of the four Canadian forestry schools in recognition of the best essay on a forestry subject.

In 1948, Canada received another $\$ 220.00$, which was added to the original $\$ 300.00$, making it possible to present the prize annually. In 1952 an additional $\$ 295.00$ was added. The annual prize was then raised from $\$ 24.00$ to $\$ 35.00$. It has since been increased several times and in 1991 was $\$ 150.00$, and now goes on rotation to graduates of six forestry schools.

(1) For. Chron. 68: 152-153, February 1992.

The Recipients of the Schlich Memorial Prize

Year

1935

1936

1937

1938

1939

1940

1941

1942

1943

1944

1945

1946

1947

1948

1949

1950

1951

1952

1953

1954

1955

1956

1957

1958

1959

1960

1961

1962

1963

1964

1965

1966

1967

1968

1969

1970

1971

1972

1973

1974

1975

1976

1977

1978

1979

1980

1981

1982

1983

1984

1985

1986

1987

1988

1989

1990

1991

\author{
University \\ Toronto \\ New Brunswick \\ Laval \\ British Columbia \\ Toronto \\ New Brunswick \\ Laval \\ British Columbia \\ Not awarded \\ Toronto \\ Not awarded \\ New Brunswick \\ Not awarded \\ Not awarded \\ British Columbia \\ Toronto \\ New Brunswick \\ Laval \\ British Columbia \\ Toronto \\ New Brunswick \\ Laval \\ British Columbia \\ Toronto \\ New Brunswick \\ Laval \\ British Columbia \\ Toronto \\ New Brunswick \\ Laval \\ British Columbia \\ Toronto \\ New Brunswick \\ Laval \\ British Columbia \\ Toronto \\ New Brunswick \\ Laval \\ Lakehead \\ Alberta \\ British Columbia \\ Not awarded \\ New Brunswick \\ Toronto \\ Laval \\ Lakehead \\ Alberta \\ British Columbia \\ New Brunswick \\ Laval \\ Toronto \\ Lakehead \\ Alberta \\ British Columbia \\ New Brunswick \\ Laval \\ Toronto
}

Recipient

John A. Farrar

R. Franklin Morris

Paul H. Lachance

John W. Ker

R.E. Mullin

Stanley L. Pringle

Roland Royer

Raymond E. Foster

K.B. Lee

Donald C. Horncastle

James D. Clark

J.L. Ladell

V.H. Bushell

M. Chouinard

K.G. Boyd

Fred Motyl

J.D. Brophy

Paul E. Vézina

George Nagle

H.D. Griffin

Carl. H. Winget

Jean Paul Campagna

R.A.B. MacFarlane

Edward J. Yeates

Peter H. Kourtz

Gaston Provencher

Allan Van Sickle

Hans Robert Zuuring

T.W. Pierce

Jean Guy Lajoie

Gary C. Johnson

Larry S. Lambert

R.A. Waycott

Michel Laverdière

Jo Anne Stupendik

R.B. Simpson

John A. Kelvin

J.F. Couturier

F.J. Wilson

Pierre Morin

Roger Barber

Nola M. Daintith

David Waddell

Rory F. Fraser

Jean Bourquet

Susan Wiecek

George R. D'eon

Paul J. Hostin

J. Dunster

Peter J. Jofriet

Jean-Pierre Jetté

B. Cserey 


\section{Forester's Rings}

Each year all foresters graduating from the seven forestry schools in Canada are presented with a forester's ring. It is a plain silver band bearing a small embossed tree of the same metal.

The idea arose at the University of British Columbia and was initiated there in 1953. From then until 1966 U.B.C. graduates bought their own rings and organized and held their own ceremonies. At its annual meeting in 1966 the $\mathrm{CIF} / \mathrm{IFC}$ agreed to present silver rings to all future graduates of Canadian forestry schools at suitable ceremonies, beginning with the 1967 graduating classes. The Institute has presented rings annually for 25 years and the total, shown in the table below of near 7000 is impressive.

Number of Forestry Graduates who have Received Forester's Rings

$\begin{array}{cccc}\text { Year } & \text { No. } & \text { Year } & \text { No. } \\ 1967 & - & 1980 & 396 \\ 1968 & - & 1981 & 360 \\ 1969 & 152 & 1982 & 387 \\ 1970 & - & 1983 & 381 \\ 1971 & - & 1984 & 382 \\ 1972 & - & 1985 & 347 \\ 1973 & 220 & 1986 & 356 \\ 1974 & 266 & 1987 & 352 \\ 1975 & 256 & 1988 & 304 \\ 1976 & 321 & 1989 & 245 \\ 1977 & 400 & 1990 & 219 \\ 1978 & 423 & 1991 & 247 \\ 1979 & 398 & & \end{array}$

In 1979 the retiring President of the Institute was presented with a gold forester's ring and this practice has been continued annually. It is generally accepted that the gold ring will be worn only by past presidents of the Institute.

\section{Gold Medals}

The Vancouver Section in 1949 approved the presentation of a gold medal each year to the forestry student of highest standing at the University of British Columbia. The cost was to be shared with the Vancouver Island Section. The Institute, at its 1953 annual meeting, "undertook to provide annually a gold medal award to the most deserving student of the graduating class in each of the four Canadian forestry schools." This was implemented in 1954 to include the Universities of British Columbia, Toronto, Laval, and New Brunswick. It has been extended to include Lakehead University, and the Universities of Alberta and Moncton as they began graduating foresters in 1973, 1974 and 1990, respectively.

In 1991 the Institute agreed to extend presentation of Gold Medals annually to the leading forestry technician graduate in each of some 20 technical colleges throughout Canada, beginning in 1992.

In the period 1953 to 1991,191 Gold Medals were awarded:

\section{3}

James McWilliams, U.B.C.

\section{4}

Louis Schulte, U.N.B.

Louis Rousseau, Laval

Robert D. Carman, U. of T.

Robert S. Wood, U.B.C.

\section{5}

G.L. Baskerville, U.N.B.

Marius Mignault, Laval

Geoffrey Pierpoint, U. of T.

C. Harry Gairns, U.B.C.

\section{6}

Dennis Brophy, U.N.B.

Marcel Lortie, Laval

J.I. Johnston, U. of T.

Peter H. Pearse, U.B.C.

\section{7}

John Torunski, U.N.B.

Jacques Gauthier, Laval

David C.F. Fayle, U. of T.

R. Smith, U.B.C.

\section{8}

C.L.H. van Vredenburch, U.N.B.

Pierre Dorion, Laval

William Hannaford, U. of T.

Everett B. Peterson, U.B.C.

\section{9}

Gary L. Saunders, U.N.B.

Marcel Roberge, Laval

H.D. Griffin, U. of T.

J.E. Harris, U.B.C.

\section{0}

Carl Winget, U.N.B.

Damien Bourgoin, Laval

Bert Post, U. of T.

John Revel, U.B.C.

\section{1}

Harry Boyles, U.N.B.

Luc Valiquette, Laval

E.B. MacDougall, U. of T.

R.W. Haigh, U.B.C.

\section{2}

J.D. Mitchell, U.N.B.

Denis Lachance, Laval

L.S. McCoy, U. of T.

Lorne G. Brace, U.B.C.
1963

D.M. Levy, U.N.B.

Marc Côté, Laval

L.T. Kirby, U. of T.

M.J. Kempston, U.B.C.

\section{4}

Peter H. Kourtz, U.N.B.

Jean-Marie Pouliot, Laval

A.C. Woodland, U. of T.

John Konkin, U.B.C.

\section{5}

S.J. Williamson, U.N.B.

Gilbert Paillé, Laval

J.R. Powell, U. of T.

Fred L. Bunnell, U.B.C.

\section{6}

R.K. Carty, U.N.B.

Jean-Louis Brown, Laval

L.O.W. Burridge, U. of T.

G.M. MacDermid, U.B.C.

1967

R.J. Drysdale, U.N.B.

Marcel Brazeau, Laval

R.D. Ayling, U. of T.

R.P. Willingdon, U.B.C.

1968

S.J. Beaufoy, U.N.B.

M.A. Lalonde, Laval

F.J. Hutcheson, U. of T.

Terence Lewis, U.B.C.

\section{9}

J.T. O'Leary, U.N.B.

Claude Godbout, Laval

P.A. Cooper, U. of T.

R.J. Pearson, U.B.C.

1970

John Hreno, U.N.B.

Guy Noel, Laval

Sherry L. Hambly, U. of T.

A. Les Brown, U.B.C.

1971

R.A. Waycott, U.N.B.

Michel Hamel, Laval

T.J. Burton, U. of T.

K.H. Baker, U.B.C

1972

M.L. Willick, U.N.B.

Denis Soucy, Laval

M. Sara M. van der Eyk, U. of T.

David S. Bishop, U.B.C.

1973

Henri Chojnacki, U.N.B.

Yvon Racine, Laval

C.G. Zinkan, U. of T.

Malcolm McIntyre, L.U.

David J. Meehan, U.B.C.

1974

B.S. Chisholm, U.N.B. 
Michael Doyon, Laval

V. Dobrobolsky, U. of T.

Garry Bloomfield, L.U.

D.A. Sklar, U. of A.

G.E. Mancell, U.B.C.

\section{5}

E.W. Robak, U.N.B.

Clement Bordeleau, Laval

A.J. Willcocks, U. of T.

J.D. Phillips, L.U.

B.L. Phillips, U. of A.

M.O. Otterloo, U.B.C.

\section{6}

Brent Evered, U.N.B.

Giles Trudel, Laval

P.L. Marshall, U. of T.

W.A. Kenney, L.U.

Dale Darrah, U. of A.

Richard S. Sommer, U.B.C.

1977

Keith Jones, U.N.B.

Mario Blanchet, Laval

Paul C. Ward, U. of T.

Paul G. Butra, L.U.

Margaret J. Hee, U. of A.

Mary Elizabeth Suttie, U.B.C.

\section{8}

Roger J.J. Roy, U.N.B.

Claude Gignac, Laval

Sandra L. Dart (Runk), U. of T.

Reino E. Pulkki, L.U.

John C. Pollack, U. of A.

Alan J. Walters, U.B.C.

\section{9}

Thomas A. Erdle, U.N.B.

Pierre Morin, Laval

Brian A. Barkley, U. of T.

Richard Watson, L.U.

Lois H. (Pelchat) Dellert, U. of A.

Robin John Dorey, U.B.C.

\section{0}

W.L. Meyer, U.N.B.

Francois Seguin, Laval

John M. Fullerton, U. of T.

James D. Sutherland, L.U.

Byron Grundberg, U. of A.

Dan Scott Price, U.B.C.

\section{1}

Michael J.J. Connors, U.N.B.

A. DuSault, Laval

L. Vanderstar, U. of T.

Peter DeGroot, L.U.

Nola Daintith, U. of A.

Heather Jane Cook, U.B.C.

\section{2}

W.R. Thornton, U.N.B.

M. Michel Villeneuve, Laval

Colin Hewitt, U. of T.
Paul Krabbe, L.U.

Terry Kristoff, U. of A.

David Waddell, U.B.C.

\section{3}

Alan L. Anderson, U.N.B.

Danielle Legault, Laval

William S. Garton, U. of T.

Robert Mitchell, L.U.

Janice M. Traynor, U. of A.

B.W. Bergstrom, U.B.C.

\section{4}

William A. Davis, U.N.B.

John McKay, Laval

Sarah Thompson, U. of T.

David Tarjan, L.U.

Nora P. Kopjar, U. of A.

Perry M. Monych, U.B.C.

\section{5}

Shelley A. Vesico, U.N.B.

Jean-Martin Lussier, Laval

Dorli M. Duffy, U. of T.

Raymond Wagner, L.U.

Laurie Onishenko, U. of A.

Laurie Kremsater, U.B.C.

\section{6}

Philippe B. LeBlanc, U.N.B.

J.F. Côté, Laval

Silvia Strobl, U. of T.

Sylvia G. Lagen, L.U.

Glenn Farrow, U. of A.

Michael Douglas Kerr, U.B.C.

1987

Robert L. Colpitts, U.N.B.

Leon Belanger, Laval

Andrew John Mayes, U. of T.
Andrea Marie McDonald, L.U.

Kim Young, U. of A.

Cindy Lee Fox, U.B.C.

1988

F.E. Oberle, U.N.B.

Julie Chagnon, Laval

Naomi Donat, U. of T.

Scott Mitchell, L.U.

R. Prins, U. of A.

R.J. Robazza, U.B.C.

1989

E.R. Wilson, U.N.B.

Jean-Pierre Jetté, Laval

Dan Kneeshaw, U. of T.

E.H. Hoffman, L.U.

Caroline Kutash, U. of A.

W. Stump, U.B.C.

1990

Roy Cumberland, U.N.B.

Guy Serry, U. of Moncton

Solange Nadeau, Laval

Chris P. McDonnell, U. of T.

T.G. Payne, L.U.

Ken Greenway, U. of A.

Jonathan Mark S. Moss, U.B.C.

1991

Darren Fillier, U.N.B.

Emanuel Sildor, U. of Moncton

Luc Fréchette, Laval

Andrew Dunlop, U. of T.

Douglas Maki, L.U.

J.R. Harris, U. of A.

Lawrence C. Chrobot, U.B.C.

\section{D.R. Redmond, Chairman} Archival Committee

\section{ABCPF/CIF Cooperation}

In December 1990 the executive of the Association of B.C. Professional Foresters and Canadian Institute of Forestry appointed a task force consisting of two members representing each organization. The task force was to address the need to improve cooperation, coordination and efficiency of ABCPF/CIF activities. The two organizations were particularly interested in receiving recommendations on how we could reduce duplication and improve performance at the regional (section) level. It has been apparent to those involved that many regional activities have been sporadic and ineffective. To date, efforts by the two organizations to correct this problem have been unsuccessful.

The task force reported on November 21, 1991 and recommended a radical change to the structure and mandate of both organizations. Task force members felt that a major change was the only solution to our concerns over the long term. They felt that the current structures, duties and roles of the ABCPF and CIF are an impediment to addressing important forestry and professional issues, especially at the regional and provincial level.

The executives of the ABCPF and CIF have taken the recommendations under review and met in February to determine how to proceed. We anticipate considerable discussion with members of both organizations during 1992 , leading to a new and productive partnership between the two organizations. 